\title{
Costs and returns in commercial broiler rearing in Dharwad district
}

SHREYA V. AMARAPURKAR, C. MURTHY AND B.K. NAIK

Received : 06.08.2014; Revised : 20.08.2014; Accepted : 01.09.2014

\begin{abstract}
The Indian poultry industry has grown largely due to the initiative of private enterprises. Poultry farming in India is a culmination of many years of innovation. Poultry farming in India has been a huge success in the last decade. Statistics showed a 2 per cent increase per annum in the agricultural production during the last 30 years, while the growth in the poultry sector has been 12 per cent which gives an idea about how well this industry is doing. Per unit cost decreases with increase in the size of farms signifying the economies of scale. The problem of high wage rate was the major problem expressed by the farmer respondents. The losses due to disease occurrence was severe problem as the hatchery will be taking lot of precautions on the mortality of birds in recent years so this was the problem expressed at the last. Thus, in nutshell, the broiler farming is a profitable venture and has a bright future in the study area for improving economic status of the farming community.
\end{abstract}

KEY WORDS : Cost and return, Commercial broiler rearing, Poultry farming, Cost and return

How to cite this paper : Amarapurkar, Shreya V., Murthy, C. and Naik, B.K. (2014). Costs and returns in commercial broiler rearing in Dharwad district. Internat. J. Com. \& Bus. Manage., 7(2) : 316-319.

MEMBERS OF THE RESEARCH FORUM

Correspondence to:

SHREYA V. AMARAPURKAR, Department of Agri-business Management, University of Agricultural Sciences, DHARWAD (KARNATAKA) INDIA

Email: shreya.amarapurkar@gmail.com

Authors' affiliations:

C. MURTHY AND B.K. NAIK, Department of Agri-business Management, College of Agriculture, University of Agricultural Sciences, DHARWAD (KARNATAKA) INDIA 